\title{
Improving English Comprehension in Primary School by Picture-books Story-telling and Reading
}

\author{
Chen Rongyi \\ Hefei Qingnian Road Primary School \\ 488 Huizhou Boulevard, Hefei, Anhui, \\ China. \\ 44086917@qq.com
}

\begin{abstract}
So many Chinese students graduated from university after having learned English for 12 years, but they can't use English well, especially in English listening and speaking. However, all these college students passed Band 4 test of CET (College English Test). There are many reasons for this strange phenomenon but the most important one is Chinese teaching system which is badly influenced by testing system. This year (2013), Chinese education department are under discuss whether the English test will be taken out of National Examinations of College Entrance or the total score should cut down from 150 to 100. It has reflected that our country is in a dilemma whether we should take English into NCEE (National College Entrance Examinations) or not. However, the problem is not exams but how to test and how to teach English in schools.

As a primary school teacher for 16 years, the writer has found out that all teachers have to use a textbook to teach and have to finish the textbook and take exams according to the book. If students do better in exams, teachers' value will improve. Otherwise, they will not be welcomed by school headmaster. These really hold back our English teaching. All our teachers are thinking about how to help students achieve high score not language function, that, understanding and communication.

After many years teaching, the writer has found out that English learning goes well with exams. In order to prove this, the writer began an experiment which lasted for 10 weeks during which the writer read picture-books to students at every class for ten minutes. The students really enjoyed the stories. This method really enhances students' interests and abilities in listening, speaking and understanding. This article focuses on the picture-books reading to improve the comprehension of English reading in primary school.

Reading picture-books improve students' comprehension and teachers' teaching approaches. It will benefit all the students if this teaching method applies to all students who are learning English. As no one in China has done this research before, the writer thinks this article can apply to many primary schools in China.
\end{abstract}

Keywords: English comprehension, primary school, picture books, story-telling, reading 


\section{Introduction}

So many university students graduated from university after having learned English for 12 years, but they can't use English well. The problem is caused by our testing system.

Students learn English only for tests not for real use. If they pass a test, they will not touch English any longer. Our language learning is targeted for exams not for the real use of English. Students are only interested in tests and teachers are only interested in how to help students get high scores. This leads to a strange phenomenon that students get high marks in tests but can't understand people who speak English and foreigners can't understand our students' English either.

This article focuses on the picture-books reading to improve the comprehension of English listening, speaking and reading in primary school. As no one in Hefei has done this research before, the writer thinks this article can apply to many primary schools in Hefei.

\section{Problem Identification and Analysis Problem Identification}

The writer found many students even college students, after 14 years of learning (from Grade 3 to university), still can't understand English well. There are many reasons for this weird phenomenon. One of them is that our teachers teach English only for tests or high scores not the use of English. That is also because of teaching system which is making all our teachers teach English in that way.

Having taught English for more than 16 years, the researcher found that the problem starts from primary schools to university. Different learning stages have different problems. This essay pays attention to the problem in primary schools or elementary schools, for the author have been teaching English in primary schools for more than 16 years.

The writer found out that most our teachers in primary schools have been using the bottomup methods. The "bottom up" approach stipulates that the meaning of any text must be "decoded" by the reader and that students are "reading" when they can "sound out" words on a page. (Phonics). It emphasizes the ability to de-code or put into sound what is seen in a text. It ignores helping emerging readers to recognize what they, as readers, bring to the information on the page. This model starts with the printed stimuli and works its way up to the higher level stages. The sequence of processing proceeds from the incoming data to higher level encodings( http://www.nadasisland.com/reading/)

Teachers teach students words first, then phrases, sentences, and last passages. According to their understanding, they think that if students can't understand the words, how come they can understand the phrases not mentioning the passages? Thus, our students begin learning English from the alphabets which they have to remember how to sound and how to write. Then they have to remember every single word including meaning, spelling and pronunciation. And then they have to remember the phrases, like "let sb. do sth, make sb do sth, to see sb. do/doing sth." etc. Students lose their interests in English gradually until they reach junior high school, they only learn English for tests not for fun and for real use. 


\section{Analyze the project problem}

In order to find out the problem in primary school, the writer used different methods. Two methods of problem analysis are exactly used to analyze the problem. They are Socratic Dialogue and Cause Analysis.

\section{Socratic Dialogue}

At this stage, the researcher asked a series of questions and then answered them.

\begin{tabular}{|l|l|}
\hline Questions & Answers \\
\hline $\begin{array}{l}\text { a) What do students like to do in an } \\
\text { school? }\end{array}$ & $\begin{array}{l}\text { They like to read interesting picture-books, } \\
\text { eg, Chika chika boom boom, There is a bird } \\
\text { on my head, the foot book, etc. }\end{array}$ \\
\hline $\begin{array}{l}\text { b) What are students expected to } \\
\text { do with the books? }\end{array}$ & $\begin{array}{l}\text { They should understand what they read } \\
\text { with or without English words. }\end{array}$ \\
\hline $\begin{array}{l}\text { c) What can students do with the } \\
\text { books? }\end{array}$ & $\begin{array}{l}\text { They can tell the story with the help of } \\
\text { books. They should tell stories to students } \\
\text { or parents with the books as a good model } \\
\text { for students and as a good teaching } \\
\text { material }\end{array}$ \\
\hline $\begin{array}{l}\text { d) How did the teacher deal with the } \\
\text { books? }\end{array}$ & $\begin{array}{l}\text { Just asked to buy or borrow the books and } \\
\text { then asked students to read silently by } \\
\text { themselves. }\end{array}$ \\
\hline $\begin{array}{l}\text { e) What did the teacher do to } \\
\text { develop the students' ability of reading } \\
\text { comprehension? }\end{array}$ & Nothing. \\
\hline
\end{tabular}

Table 1: Socratic Dialogue for Problem Analysis

\section{Cause analysis}

This analysis starts with some factors that may contribute to the cause: the teacher's side, the students' side as well as the techniques for picture-books reading.

\section{a) Teacher's side}

In primary schools, teachers focus on text books. They wonder when they will finish the books-teaching so teachers usually give some picture books and ask students to read them. They don't have too much to spare for students to read picture-books not mentioning the teachers reading picture-books. What's worse, some teachers even just give the names of picture books and ask them to get the books and then read them. Teachers (both Chinese teachers and English teachers) in primary school always think reading books are kind of after-class activities, and there is nothing related to the class activities. Both Chinese and English teachers just think reading books are for fun and widening students' view of the world. They've just missed the most important part of the reading books-learning and supplying for what students can't get in class or in text books. 


\section{b) Students' side}

Students like English picture books but only pictures, not the words because our students are Chinese. They couldn't understand all the words, phrases or sentences in the books. They just want to find the easiest way to read the books. If they couldn't, they will give up reading picture books. As a result, though there are a lot of English picture books in the library, few of them are borrowed to read by students. They need the help of teachers who can give students advice, suggestions and methods of reading English picture books or in the future English fictions or nonfictions.

\section{Techniques for teaching vocabulary}

Our teachers in primary schools teach students words in a bottom up method. They show students word cards, relics or PPTs for students, and then ask students to remember them, that is the object, the spelling and the sound. Teachers use just one word for one picture. There are no connections between words. For example, they teach apple just apple, red just red. They never think of a red apple or a juicy apple etc. because they think red is not in the page of text book.

In middle school, teachers only care about exams, not the skill of listening, speaking, reading and writing. Of course, this is what we talk about in our essay today.

\section{Results of Problem Analysis}

According to the above problem analysis, we can see that student's comprehension has not been improved since primary schools. We must improve students English comprehension skill from primary school.

\section{Project Objective and Hypothesis Project Objective}

The project objective is to develop the students' English listening, speaking and reading comprehension so that they can get more information from English picture-books.

\section{Project Hypothesis}

It is hypothesized that students' ability to get the information when reading picture-books can be improved more effectively using story-telling by teachers and then reading by students themselves. This hypothesis can be proved by their figuring out more of the main ideas in the story on their own.

\section{Project Rationale}

Research about Top-down processing

The current view of English reading distinguishes between two key processes. One way is known as the "bottom up processing" as we discussed above in 2.1 Problem Identification and Analysis. The other process is known as the "top down processing" The "top down" approach emphasizes readers bringing meaning to text based on their experiential background and interpreting text based on their prior knowledge (whole language) (www.nadasisland.com/reading).

Reading is essentially a process of predicting and confirming language. This idea can be easily understood if we consider our experience of reading in our first language. Clearly 
when we read in our mother tongue, we do not read to every word, but we can guess a lot of what is going to be read since language is full of patterns and certain situations, which will be very familiar to us. We can often predict what is going to be read next.

Even we can ignore some mistakes in reading and correct them automatically, for example, " 研表究明, 汉字序顺并不定一影阅响读。”, well, the correct order is “研究明表, 汉字顺序并不 一定影响阅读”

Our brain and eyes rearrange the words automatically. And this is the same in English language, for example: According to a research project at Cambridge University, it doesn't

mttaer waht oredr the Itteers in a wrod are, the olny iprmoatnt tihng is taht the frist and Isat Itt eer be in the rghit pclae.

The correct order should be according to a research project at Cambridge University, it doesn't matter what order the letters in a word are, the only important thing is that the first and last letter be in the right place. This is because the human mind does not read every letter.

"The top-down reading model theory encourages students to focus more on understanding the main ideas of a passage than understanding every word. Even if students do not understand each word, they are likely to grasp the meaning of a text as a whole. Babies learn to speak much the same way. Instead of teaching words one at a time, parents use conversation to teach language to their children." (Amy Pearson, http://everydaylife.globalpost.com/topdown-reading-model-Theory13028. html)This is because the human mind does not read every letter.

\section{Research about comprehensible input}

Reading plays an essential role in the daily lives of most people. It is functional when people read road signs, maps, recipes, labels, fill forms, or apply for jobs that are unique to our daily lives. It is fundamental to school achievement, and hence, learning to read at the appropriate time is crucial to one's academic success. All school subjects require reading various written materials like graphs, charts, maps and tables. In Kaplan's(1986) opinion, failure to learn to read by the end of Primary one (i.e., first grade) is associated with later academic failure. Samuel Kewaza,2013) Kavcar, Oğuzkan, and Sever (1997, p. 41) evaluates reading as "the process of seeing, perceiving and comprehending the words, sentences, punctuation marks and the other elements of a writing". Sever (1997) defines reading as regards to mental processes. In other words, reading is not only voicing the letters. It is very important to explain the meanings and interpret the voiced letters (Gürses, 1996). A connection is established between the writer and the reader through reading and the reader is expected to understand the message that the writer aimed to convey. As it can be understood from this, reading has three dimensions (Demirel, 2000, p. 77). There are many sources to contribute to language input in the classroom, such as the teacher, the students themselves and of course, the stories, which are in the broadest sense (Ur, 2000a). Nevertheless, in the reading process, "...the learner is an active participant. In order to comprehend, readers need to reconstruct the original intention of the writers by making use of both bottom-up and top-down processing strategies, and by drawing on what they already know to make use of new knowledge" (Nunan, 2001: 211). 


\section{Research about interactive approach}

For those reading theorists who recognized the importance of both the text and the reader in the reading process, an amalgamation of the two emerged the interactive approach. Reading here is the process of combining textual information with the information the reader brings to a text. (http://www.nadasisland.com/reading)

The interactive model (Rumelhart 1977; Stanovich 1980) stresses both what is on the written page and what a reader brings to it using both top-down and bottom-up skills. It views reading is the interaction between reader and text.

The overreliance on either mode of processing to the neglect of the other mode has been found to cause reading difficulties for SL learners (Carrell 1988, p. 239)

The interactive models of reading assume that skills at all levels are interactively available to process and interpret the text (Grabe 1988).

In this model, good readers are both good decoders and good interpreters of text, their decoding skills becoming more automatic but no less important as their reading skill develops (Eskey 1988).

\section{Advantages of picture-books storytelling and reading}

All children love stories. Reading stories to children can be a central part of classroom life which is very unusual in China. There are many advantages of picture books storytelling and reading, such as:

1) Pictures tell stories. The writer or the illustrator of a picture book draws very unusual pictures. Teachers can find many things we want according to their teaching objects.

2) Stories are motivating so that students will always be willing to listen or read by themselves.

3) Stories are rich in language experience. Students want to find meaning in stories, so they listen or read with a purpose.

4) Stories can enhance students' listening, speaking and reading skills. When they listen and read the stories, there is a positive attitude to not understanding everything. So their skills of searching for meaning, predicting and guessing are trained as well.

5) Stories help students become aware of the general 'feel' and form of the foreign language. The language point, which including vocabulary and the sentence structures, are introduced and made familiar through stories.

6) Picture-books in preschool level or level one reading standard are full of language patterns which is easy to listen and follow and easy to remember as well so student can read by themselves after teachers stories telling.

7) Picture-books storytelling need students' involvement. Students look at the pictures and listen to teachers telling and then answer the questions about the pictures or what heard and saw a while ago.

Drawing on the above theories, we decide that story-reading can be a good top-down device to solve the problem identified in this project, as stories are interesting and can actively involve the students as more "motivated participants"; and in most cases, the stories are slightly more advanced than the students' current language level, but given the context of the story, those otherwise incomprehensible contents may turn out to be "comprehensible input" (Harmer, 2000). 


\section{Project Design}

Drawing on the discovery of the problem analysis and rationale quoted above, a project is designed to improve the students' reading ability by integrating storyreading in their classroom learning.

\section{Research tools}

Five data collection instruments will be used in the research: pre-test (see Appendix IV), post-test (see Appendix V), reflection notes (see Appendix III), pre-questionnaire (see Appendix $\mathrm{VI}$ ), and interview notes (see Appendix VII)

\section{Target group and Control group}

Two groups of students will be needed for comparison, the Target group, who will use the innovative picture-books story-telling and reading method, and the Control group, who will be taught in the same traditional way. The sample groups consisted of two classes of Grade 3 students, who were about the same English level at the beginning of the project. They were taught by the same teacher, but in different ways. Students of Class 4, Grade 3 comprised the Target class and used for picture-books story-telling and reading practice. There are 3 English teaching periods in a week. Every period has 40 minutes. They were asked to spend 10 minutes to listen to a picture-book story in each 40-minute period. Then they borrow the same book from school library and take it home to read or read in library. Students of Class 5 , Grade 3 served as the Control Group and continued to use traditional method, namely, the bottom-up method, to practice English reading.

\section{Teaching materials}

5 picture books will be needed in the project. They should be suitable for the students' present English level and the content should be related to the students' curriculum so as not to interrupt their normal learning plan. 5 picture books (See Appendix I) were selected by the researcher and the teacher (here it is the same person) from the school library. The content of the 5 picture books were relevant to students' normal English lesson topics, such as colors, fruit, animals, body parts and school rules.

\section{Story-telling and reading design}

A ten-week story-telling and reading lesson plan was designed by the researcher, based on the project objective, and especially pertinent to the students' problems as analyzed in 2.2 Problem Analysis.

The project will last for ten weeks and have 5 periods, which include 5 picture books and 13 tasks. The table below is an overview of the project design: 


\begin{tabular}{|c|c|c|c|c|c|c|}
\hline Period & Week & Date & Story & Objectives & Tasks & $\begin{array}{l}\text { Time } \\
\text { (Min) }\end{array}$ \\
\hline \multirow{3}{*}{1} & \multirow{3}{*}{ I\&II } & \multirow[t]{3}{*}{$\begin{array}{l}\text { Sept. } \\
16\end{array}$} & \multirow{3}{*}{$\begin{array}{l}\text { Lemons } \\
\text { are not } \\
\text { red? }\end{array}$} & $\begin{array}{l}\text {-To make } \\
\text { students enjoy } \\
\text { the story. }\end{array}$ & \multirow{3}{*}{$\begin{array}{l}\text { 1. Brainstorm what } \\
\text { they have seen and } \\
\text { heard } \\
\text { 2. Listen and guess } \\
\text { the colors } \\
\text { 3. Question and } \\
\text { answer } \\
\text { 4. Prepare a short } \\
\text { play. }\end{array}$} & \multirow{3}{*}{$10 * 6$} \\
\hline & & & & $\begin{array}{l}- \text { To become } \\
\text { aware of the } \\
\text { general "feel" of } \\
\text { the foreign } \\
\text { language. }\end{array}$ & & \\
\hline & & & & $\begin{array}{l}\text {-To guide } \\
\text { students read for } \\
\text { response by } \\
\text { showing the } \\
\text { pictures. }\end{array}$ & & \\
\hline 2 & III\&IV & Sep.29 & Colors & $\begin{array}{l}- \text { To help } \\
\text { students read for } \\
\text { the purpose and } \\
\text { get the main } \\
\text { ideas }\end{array}$ & $\begin{array}{l}\text { 5. use TPR to } \\
\text { understand the } \\
\text { language. } \\
6 \text {. Have a competition } \\
\text { with students to see } \\
\text { who understand first }\end{array}$ & $10^{\star} 6$ \\
\hline 3 & $\mathrm{~V} \& \mathrm{VI}$ & Oct.14 & $\begin{array}{l}\text { Go away, } \\
\text { big green } \\
\text { monster }\end{array}$ & $\begin{array}{l}\text {-To guide } \\
\text { students to read } \\
\text { the }\end{array}$ & $\begin{array}{l}\text { 7. Answer the } \\
\text { questions step by } \\
\text { step. } \\
\text { 8. Complete the table } \\
\text { to focus on some } \\
\text { specific information. }\end{array}$ & $10^{*} 6$ \\
\hline 4 & VII\&VIII & Oct..21 & Foot book & $\begin{array}{l}\text {-use TPR to help } \\
\text { students } \\
\text { understand the } \\
\text { language }\end{array}$ & $\begin{array}{l}\text { 10. Predict what will } \\
\text { happen next. } \\
11 . \text { Try to tell the story } \\
\text { to the class. }\end{array}$ & $10^{\star} 6$ \\
\hline 5 & IX\&X & Nov. 4 & No, David & $\begin{array}{l}\text {-To help the } \\
\text { students } \\
\text { understand } \\
\text { some of the } \\
\text { vocabulary and } \\
\text { the grammar, } \\
\text { and then try to } \\
\text { tell stories to the } \\
\text { others. }\end{array}$ & $\begin{array}{l}\text { 12. Talk about the } \\
\text { rules at school so they } \\
\text { can build up the } \\
\text { background } \\
\text { knowledge. } \\
\text { 13. make some rules } \\
\text { for class. }\end{array}$ & $10^{*} 6$ \\
\hline
\end{tabular}

Table 2: Timetable of Project

\section{Project Implementation}

Here is the lesson plan for the first two weeks for illustration, and all the lesson plans can be found in Appendix II. 
Week I \& II-- book 1: Lemons are not red.

Time: $6^{*} 10$ minutes

Content: fruit and colors

Materials: a picture book, Lemons are not red.

Objective: The purpose of this story is to make students enjoy the story and become

aware of the general "feel" of the foreign language

Procedures: 1. Brainstorm. Get the students to look at the story book to figure out what fruit they can see.

2. Read and say. Get the students look at the big book and read it then tell us what words they see.

3. look and guess. Lemons are not red. They are.....(yellow). ........(apples) are red..

4. Listen and answer the questions. Get the students listen to the story again, then answer the questions:

a) What color are lemons?

b) What are red?

c) What color are flamingos?

d) What are gray?

5. Assign homework. The students are supposed to borrow the book from the library and read the picture book to their parents at home.

All the picture books are chosen for students to enjoy English and different thinking form Chinese people. They are all connected with students life. For example, colors, fruits, animals, body parts and school rules. The picture books are all drawn in colors and few words, so they are easy for students to understand.

The activities for each story are relevant to students' reading enhancement, such as brainstorming what they have heard, predicting and guessing the next picture of the story, answering the questions to get the general idea, filling charts to know the specific information about the story, doing True or False exercises to obtain the detailed knowledge. In addition, these activities will allow students to focus on the top-down method to practice listening.

\section{Data collection}

\section{Pre and Post-test}

Both classes will be pre-tested and post-tested at the beginning and end of the project. The post-test should be similar to the pre-test so that the results of the two tests will be comparable.

\section{Reflection Notes}

The teacher is supposed to keep teaching diaries after each lesson to help record the students' response and the teacher's own observation. The researcher himself takes the reflection notes after each lesson.

\section{Questionnaire}

After the post-test, the Target Group will be asked to fill out the post-questionnaire (See Appendix $\mathrm{VI}$ ) to investigate their attitudes and opinions about the storyreading, and showing the result of the project as well. 


\section{Interview}

During the process of the project, the researcher interviewed all students from the Target Group to find out their perceptions of this new way of teaching. The interview questions are included in the Appendix (The researcher has designed a flow chart (See Appendix VIII) to monitor the progression of the project)

\section{Students' perception of the new method}

Students' opinion of the new teaching method is obtained through the post-questionnaire and the post-interview. Their answers are presented and analyzed to reflect how well the picturebook story-telling method has been accepted by the students.

\section{Students' answers to the post-questionnaire}

To Question 1 of the questionnaire (see Appendix VI) after the whole teaching, "Which one do you prefer, the storytelling or the normal way of teaching", 37 out of 48 students chose the storytelling method, which means that $77 \%$ of them feel positively towards picture-books storytelling and reading.

To Question 2, "How much do you think your listening, speaking and reading interest increased through listening stories", more than half of the students (29) think their listening, speaking and reading interest has been increased significantly (see Graph 1) and 17 other students admit that they have been slightly more interested. Only 2 students feel that there is no change.

To sum up, the results for the two questions proved that the picture books storytelling in this project met the needs and interests of the majority of the students.

number of Students: 48

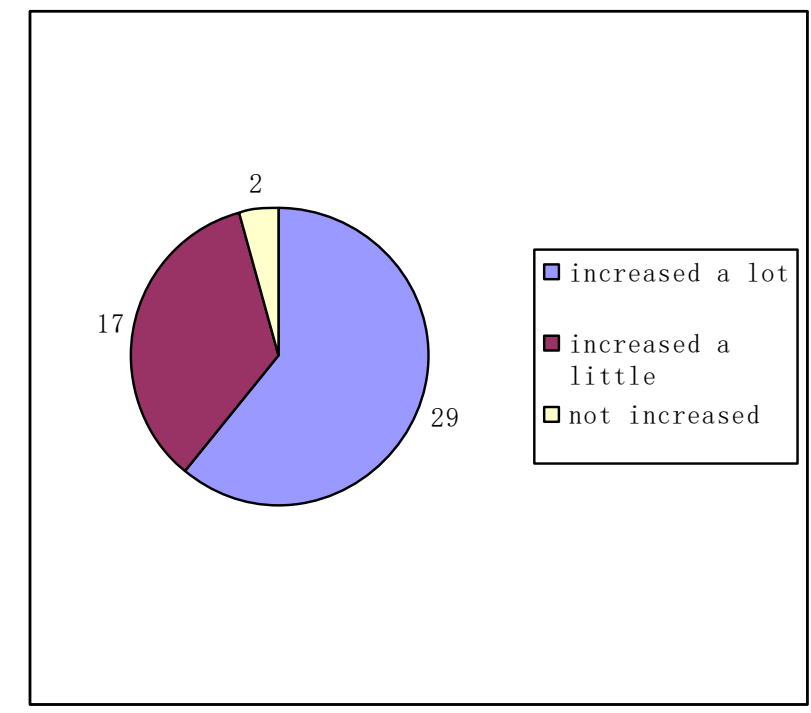

Graph 1: Students' evaluation on listening, speaking and reading interest 


\section{Students' answers in the interview}

In the interview, all of the students said they have become more interested in listening to and reading the English picture books and the main reason is that stories have beautiful pictures and plots and are not boring and mechanical as the drills they had before. This revealed, in general, storytelling is well accepted by the students and helped enhance their motivation in English listening.

\section{Students' self-evaluation in the questionnaire}

Only the post-questionnaire answers will be considered to determine the students' selfevaluation of their performance in the new pedagogical arrangement.

To Question 3 in the questionnaire, "How much do you feel you can understand the stories told in your English lessons", no students reply that he/she cannot understand the story while more than 2/3 (38 students) feel they can understand most of the story. Graph 2 shows the students' evaluation on listening comprehension.

Number of students: 48

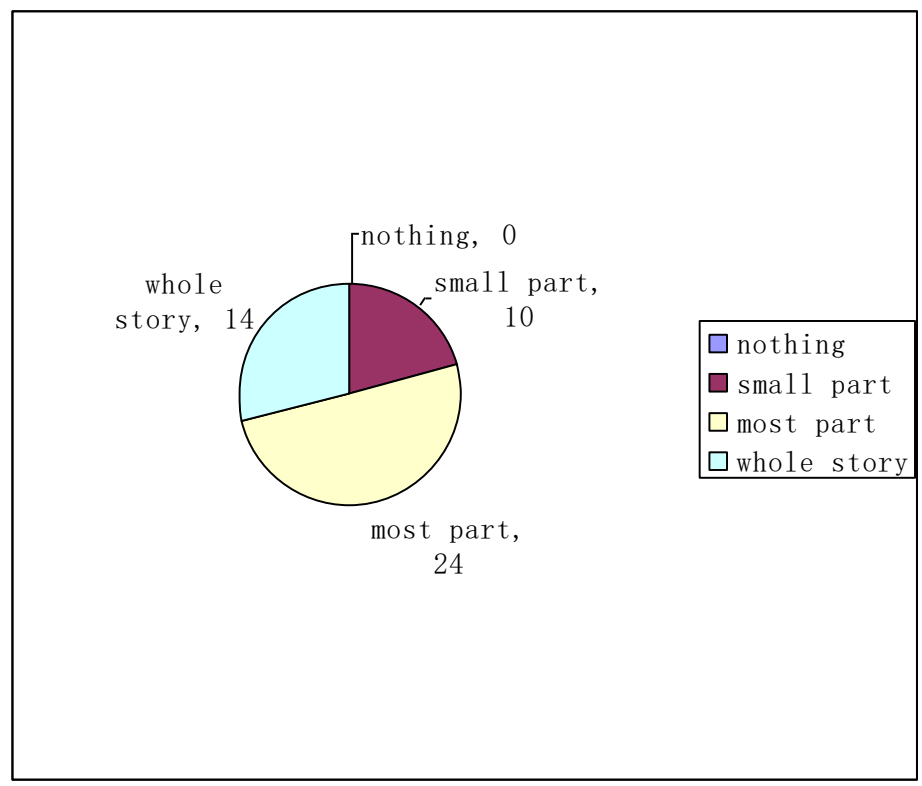

Graph 2: Students' evaluation on listening comprehension

To Question 5, "How much do you feel your listening ability has improved during the ten weeks?", although two students felt no changes during the project implementation, all the other 46 students felt that they made more or less improvement (see Graph 3). 
Number of students: 48

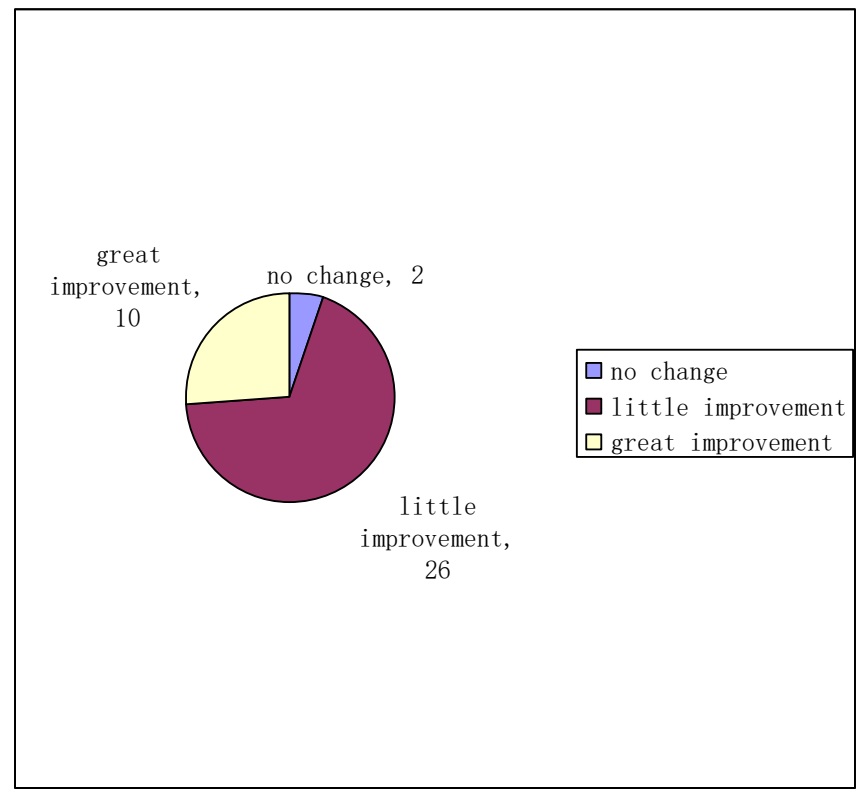

Graph 3: Students' evaluation on listening, speaking and reading ability

From the above analysis implies that picture-books storytelling is a natural and effective way of fostering children's comprehension through listening, answering and reading.

\section{Comparison of the pre-test and post-test}

Table 3 presents the results of the pre-test of the Target Group and the Control Group. As can be seen from Table 3, the students in the two groups were about the same level before the project, with the mean score of the Target Group (93.7) slightly higher than the Control Group (90.8).

\begin{tabular}{|l|l|l|l|}
\hline Group & No. of students & Total score & Mean \\
\hline Target Group & 48 & \multirow{2}{*}{100} & 93.7 \\
\cline { 1 - 1 } Control Group & 38 & & 91.8 \\
\hline
\end{tabular}

Table 3: Pre-test Scores

Table 4 presents the results of the post-test of the two groups. It shows that students of the Target Group perform better than the Control Group after the project, although the difference is still not significant (only 2.7 as compared with the 1.9 disparity in the pre-test).

\begin{tabular}{|l|l|l|l|}
\hline Group & No. of students & Total score & Mean \\
\hline Target Group & 48 & \multirow{2}{*}{100} & 93.1 \\
\cline { 1 - 1 } Control Group & 38 & & 89.4 \\
\hline
\end{tabular}

Table 4: Post-test Scores 
Comparing the means of the Target Group and the Control Group (see Graph 4), we can conclude that the students from the Target Group were making steady progress in the posttest, though the progress was not obvious.

However, we should also note that the mean score of the post-test were lower than that of the pre-test (see Graph 4). The strange phenomenon might be due to various reasons, such as not appropriate difficulty level designed for the post-test paper, lacking of the time, and so on, but it can still contribute to the conclusion that the picture-books story-telling method is superior to the traditional one.

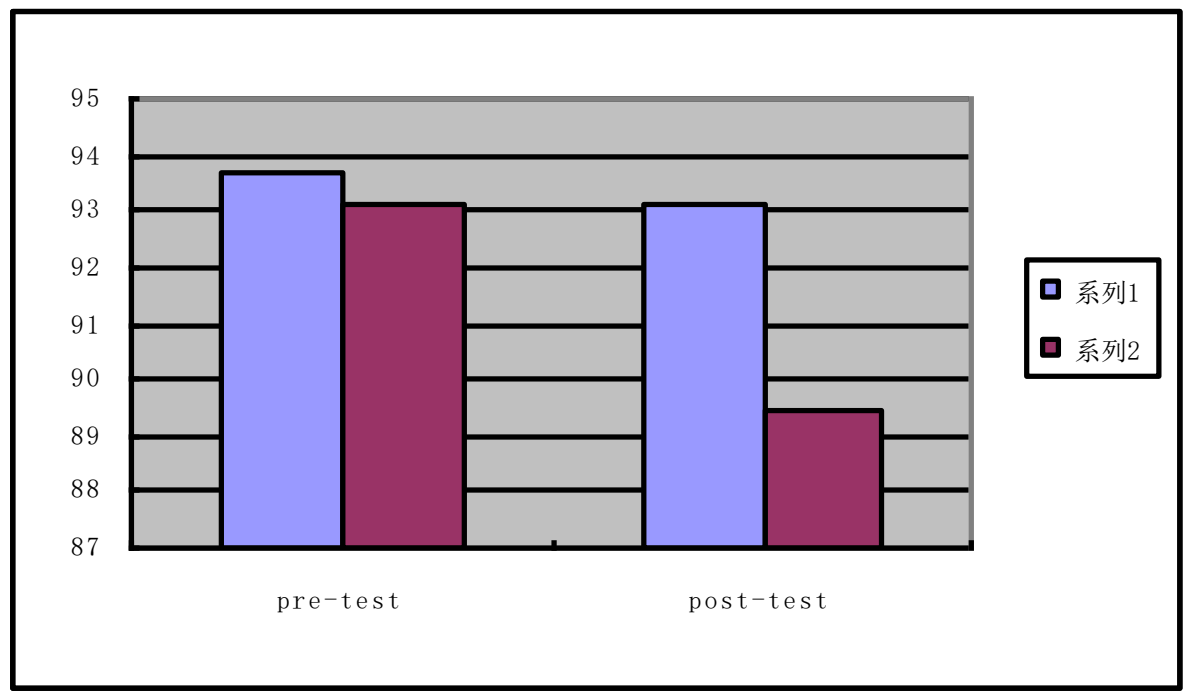

Graph 4: Comparison of the Control Group and the Target Groups

\section{Findings from the interview}

In the interview, all the students gave positive comments such as "it improves my listening, speaking and reading ability" "helps me to memorize more words" "helps me to pronounce the word correctly" and moreover, "It has broaden my horizons." (Translated by the author, see Appendix VII).

\section{Findings from Teaching Notes}

Author's reflection notes (see Appendix III) show the students are becoming more active than before; they showed great interest in picture-books and the new reading, listening and answering methods, and they are willing to read the story after class. The students made much more progress in reading and listening ability, for instance, they can understand the meaning of the story, they can predict the plot of the story though they can tell in English, and they know how to build up background knowledge, etc.

From the above data, it obviously indicates that the students benefit from the storytelling and reading after class and the methods used is helpful for the listening, speaking and reading ability enhancement. 


\section{Unsolved problems}

Despite the prevailing positive statistics result, there exist a number of unsolved problems. The following is a brief description of them.

Firstly, the research also reveals that 11 students preferred the normal teaching way, as shown to Question 1 in the questionnaire. It might be because of the reasons as follows:

1) These students relied too much on the bottom-up method for listening, speaking and reading. They were not used to the top-down method of listening, speaking and reading..

2) The picture-books provided didn't motivate them.

3) The activities the teacher did in class couldn't arouse their interests.

Therefore, for the next research, the teacher should balance the use of different methods, or in another word, make use of both bottom-up and top-down processing strategies, especially at the beginning of the change.

Secondly, according to the answers to Question 2 and 5 in the questionnaire, there were still a couple of students who did not think their listening, speaking and reading interest have been increased. And there were two students who did not think their English listening, speaking and reading ability has been improved. That might be because of the picture-books the research chose were not of the right level of these students'. Besides, the lack of time might be the other reason. Because the project took place was almost at the beginning of the semester and the beginning of English learning. We should not expect a ten-week project to reduce every problem.

Thirdly, as can be seen in Graph 4 (in 7.3), the post-test means were lower than the pre-test one. The following reasons might influence the test score:

1) The difficulty level designed for the post-test paper was much higher than the students' level.

2) The ten-week project was not long enough to make the significant achievements.

3) Some of the students might not be used to the new way of teaching.

4) Students just began to learn English, so they are not so good at English and some of them even don't know how to the test.

Therefore, the more thorough long-term plan by using picture-books storytelling and reading should be designed in the future study.

\section{Conclusion}

It has been widely recognized that listening, speaking and reading skill is among the most important skills in the language learning of primary school students, so teachers have become more concerned with developing students' listening, speaking and reading ability. However, how to better improve the students' listening, speaking and reading ability is a question unanswered. Will larger amount of bottom-up listening drills do the magic? Will some more interesting and practical listening tasks do a better job? A project was designed to help students to listen and read with a clear purpose so as to get the main ideas and specific information more effectively though enjoying carefully adapted stories.

The project was based on the rationale of top-down processing, comprehensible input, the role of the learner in the listening and participating process and the many advantages of storytelling. The project hypothesis is that using picture-books storytelling and reading will 
enhance students' listening, speaking and reading comprehension. During the implementation, the five-period picture-books storytelling and reading plan was used to meet the needs and to improve the interest of the young learners.

The project lasted ten weeks and four types of data were collected: the pre-test and post-test for both the Control Group and the Target Group, the teaching diaries by the teacher, the questionnaire for all the Target Group students and the interview of five students from the Target Group. The analysis of pre-test and post-test scores demonstrates that the mean scores of the Target Group is higher than the Control Group after the ten-week experiment, although the difference is not significant. However, all the other types of data clearly show that the Target Group perform much better than the Control Group. The teacher's reflection notes record that the Target Group become more active in class; the answers to the questionnaire reveal that the Target Group students are more interested in English listening, and the interview notes uncover that the reason of the increased interest is mainly the new element of story-telling in class. In summary, it can be concluded that the students' listening ability and interest have been enhanced by storytelling. Therefore the original project hypothesis has been proved to be correct. In a word, this project was generally successful. Therefore, for primary teachers who want to enhance students listening and reading effectively, and then develop a good habit of listening and reading, picture-books storytelling is a better choice than the normal way of teaching listening and reading which is known as bottom-up method.

Despite the positive findings and implications gained from this study, there exist a number of limitations. Firstly, more flexible method should have been used and more specific listening and reading skills should have been trained in the project so that students of different levels and learning styles can be accommodated. Secondly, due to time constraints, the ten-week project might be too short for the students to make measurable achievements in listening and reading practice, which is explains why the difference of the mean test scores between the two groups is not significant enough. Finally, the experimental lesson plan should allow some unexpected interruptions, such as the public holiday or the examination time. Therefore, continual studies should be done in the future, where a more flexible lesson plan should be adopted and a longer experiment time can be sustained. The researcher is confident that a more scientific and significant experiment result can be expected then.

\section{References}

Kewaza, Samuel; Welch, Myrtle I. Big Class Size Challenges: Teaching Reading in Primary Classes in Kampala, Uganda's Central Municipality. Online Submission, US-China Education Review A v3 n5 p283-296 May 2013

Kusdemir Kayiran, Bilge; Karabay, Aysegul. A Study on Reading Comprehension Skills of Primary School 5th Grade Students--Learning Basic Reading and Writing Skills through Phonics-Based Sentence Method or Decoding Method. Educational Sciences: Theory and Practice, v12 n4 p2854-2860 Aut 2012

N'Namdi, Kemba A. Guide to Teaching Reading at the Primary School Level. United Nations Educational, Scientific and Cultural Organization (UNESCO)

Duke, Nell K.; Block, Meghan K。 Improving Reading in the Primary Grades. Future of Children, v22 n2 p55-72 Fall 2012 
Ciampa, Katia。Reading in the Digital Age: Using Electronic Books as a Teaching Tool for Beginning Readers. Canadian Journal of Learning and Technology, v38 n2 Sum 2012

Sidek, Harison Mohd. EFL Reading Instruction: Communicative Task-Based Approach Online Submission, International Journal of Instruction v5 n2 p109-128 Jul 2012

Loh, Jason Kok Khiang. Reflecting, Shaking and Being Shook: Resistance in a Primary Classroom. English Teaching: Practice and Critique, v9 n3 p160-168 Dec 2010

\section{Appendix I.}

All the picture books, one sentence, one picture. And also some picture books have some moving parts.

Lemons are not red. Laura Vaccaro Seeger Roaring Brook Press (Aug. 22 ${ }^{\text {nd }}$, 2006)

Lemons are not red. Lemons are yellow. Apples are red.

Carrots are not purple. Carrots are orange. Eggplants are purple.

flamingos are not gray. Flamingos are pink. Elephants are gray.

Reindeer are not white. Reindeer are brown. Snowmen are white.

Grass is not blue. Grass is green. The sky is blue.

The moon is not black. The moon is silver. The night is black.

Good night!

Colors Eric Carlel Puffin books (April 20 th, 2009)

Green caterpillar, leaf.

Red apple, strawberry.

Orange orange, yellow cheese.

Blue plum, brown cocoon.

Many colors butterfly.

Go away, big green monster Ed Emberley LB Kids (April 1't, 1993)

Big green monster has two big yellow eyes,

A long bluish-greenish nose,

A big red mouth with sharp white teeth,

Two little squiggly ears,

Scraggly purple hair,

And a big scary green face!

But...

...YOU DON'T SCARE ME! SO GO AWAY, scraggly purple hair!

Go away, two little squiggly ears!

Go away, long bluish-greenish nose!

Go away, big green face!

Go away, sharp white teeth!

Go away, two big yellow eyes!

Go away, big Green Monster!

And DON'T COME BACK Until I say so. 
The Foot Book. Dr. Seuss Random House Books for Young Readers (Oct. 12 $\left.{ }^{\text {th }}, 1968\right)$

Left foot, left foot, right foot, right.

Feet in the morning, feet at night.

Left foot, left foot, left foot, right

Wet foot, Dry, high, low foot.

Front feet, back feet, red feet, black feet.

Left foot, right foot, feet, feet, feet.

How many, many feet you meet.

Slow feet, quick feet, trick feet, sick feet.

Up feet, down feet, here come clown feet.

Small feet, big feet, here come pig feet.

His feet, her feet, fuzzy fur feet.

In the house and on the street, how many, many feet you meet.

Up in the air feet, over a chair feet.

More and more feet, twenty-four feet.

Here come more and more..... and more feet

Left foot. Right foot. Feet. Feet. Feet. Oh, how many feet you meet!

No, David. David Shannon Blue Sky Press (Sept. 1 ${ }^{\text {st }}$, 1998)

David's mon always said...

No, David!

No, David!

No! No! No!

Come back here, David!

David! Be quiet!

Don't play with your food!

That's enough, David!

Go to your room!

Settle down!

Stop that this instant!

Put your toys away!

Not in the house, David!

I said no, david!

Davey, come here.

Yes, david...I love you!

\section{Appendix II.}

Week I\&II -- book 1: Lemons are not red.

Time: $6^{*} 10$ minutes

Content: fruit and colors

Materials: a picture book

Objective: The purpose of this story is to make students enjoy the story and become aware of the general "feel" of the foreign language

Procedures: 1. Brainstorm. Get the students to look at the story book to figure out what fruit they can see.

2. read and say. Get the students look at the big book and read it then tell us what words they see. 
3. look and guess. Lemons are not red. They are.....(yellow). ........(apples) are red....

4. Listen and answer the questions. Get the students listen to the story again, then answer the questions:

Q1: What color are lemons?

Q2: What are red?

Q3: What color are flamingos?

Q4: What are gray?

5. Assign homework. The students are supposed to read the picture books at home or borrow the book from the library and read to their parents at home.

Week III\&IV -- book 2: colors.

Time: $6 * 10$ minutes

Content: colors

Materials: a picture book

Objective: The purpose of this story is to make students enjoy the story and become aware of the general "feel" of the foreign language

Procedures: 1. Brainstorm. Get the students to look at the story book to figure out what colors they can see.

2. read and say. Get the students look at the big book and read it then tell us what words they see.

3. look and guess.

$\mathrm{T}$ : What color is the caterpillar?

Ss: Green.

$\mathrm{T}$ : what color is the leaf?

Ss: Green.

T: yes, it's green too. Where is the green caterpillar?

Ss: on the leaf.( some of them could answer

4. Listen and answer the questions. Get the students read the story again, then answer the questions:

Q1: What color is the caterpillar?

Q2: What color is the leaf?

Q3: What color is the apple?

Q4: What color is the strawberry?

5. Assign homework. The students are supposed to read the picture books at home or borrow the book from the library and read to their parents at home.

Week V\&VI - book 3: Go away, big green monster

Time: $6^{\star} 10$ minutes

Content: body parts

Materials: a picture book

Objective: The purpose of this story is to make students enjoy the story and become aware 
of the general "feel" of the foreign language

Procedures: 1. Brainstorm. Get the students to look at the story book to figure out what body parts they can see.

2. read and say. Get the students look at the big book and read it then tell us what words they see.

3. look and guess.

What color are the eyes?. They are.....(yellow). .what is greenish and bluish? (nose)....

4. listen and answer the questions. Get the students listen to the story again, then answer the questions:

Q1: What color are monster's eyes?

Q2: What is greenish-bluish?

Q3: What color is mouth?

Q4: What is white and sharp?

5. Assign homework. The students are supposed to read the picture books at home or borrow the book from the library and read to their parents at home.

Week VII\&VIII -- book 4: the foot book

Time: $6 * 10$ minutes

Content: all kinds of feet and rhyme

Materials: a picture book

Objective: The purpose of this story is to make students enjoy the story and become aware

of the general "feel" of the foreign language

Procedures: 1 . Brainstorm. Get the students to look at the story book to figure out what body parts they can see.

2. read and say. Get the students look at the big book and read it then tell us what words they see.

3. look and guess. This is the left foot. This is the....(right) foot. This is morning. This is night....

4. Listen to story read by the teacher and answer the questions. Get the students listen to the story again, then answer the questions:

Q1: which foot? Left or right? Good, right.

Q2: what feett? Good, right. Feet in the morning. Feet at night.

Q3: what foot? Wet foot, right. Dry foot, right.

Q4: What foot? Front foot, right. Back foot, right. ........

5. Assign homework. The students are supposed to read the picture books at home or borrow the book from the library and read to their parents at home.

Week IX\&X -- book 5: No, David.

Time: $6 * 10$ minutes

Content: rules in school and home 
Materials: a picture book

Objective: The purpose of this story is to make students enjoy the story and become aware of the general "feel" of the foreign language

Procedures: 1 . Brainstorm. Get the students to look at the story book to figure out what they can see.

2. read and say. Get the students look at the big book and read it then tell us what words they see.

3. look and guess.

This is a boy. His name is David.

He likes to play. See...

His mother said, No, David.

He wants to play food. His mother said,

No, david.(help ss say it)

...

4. Listen and answer the questions. Get the students listen to the story again, then answer the questions:

Q1: who is this boy??

Q2: what's he doing now??

Q3: What is his mother saying?

Q4: What does he want to do now?

5. Assign homework. The students are supposed to read the picture books at home or borrow the book from the library and read to their parents at home.

\section{Appendix III Reflection notes}

Reflection I

When I was reading lemons are not red to students, it was the first time for them to look at English picture books. All students opened their eyes wider to find out what was in the book because it was different from their text books. When I showed the cover to them, some students shouted out "lemon" at once. Then I asked students to look at the cover again and asked "what color is the lemon?" "Red." When I asked Are lemons red? Some of them answered?" No", others looked confused. I continued asking the students who answered "No." "What color are lemons? They said "yellow."

I confirmed them," Yes, you are right. Lemons are not red. Lemons are yellow." Then I turned over the page showing the real color of the lemon. Because this book is carved in shape of fruit and animals, one side of page is real color and the other is the color of another object. This attracted all the students because they were curious to find out what came next. This motivated them a lot and they also wanted to see whether their predictions were right or wrong. 


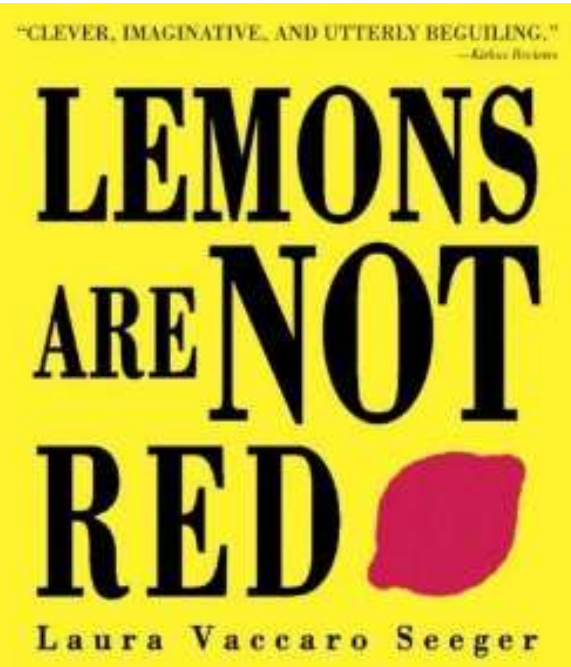

I finished reading lemons are not red in 6 teaching periods and all the students were anxious to know what was in the book, but left several pages for students to find out in the school library. This book was a successful beginning of my picture-books storytelling method which I believe will lead to fruitful ending.

\section{Reflection II}

My second picture book is colors by Eric Carle from his book my very first library.

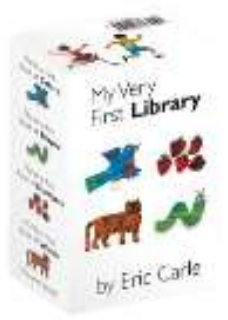

There are 4 books in this serial and chose the colors because it is connected with the book I read the first time and it is connected with our teaching topic colors as well. First, as usual, I read the first several pages to them and showed the pictures, and then I stopped because I was going to ask questions about what I read and what they saw. While I asked students to guess the color of a leaf, most of students shouted green, and this impressed me a lot because I never taught them the word "leaf" but I just read it once for them just now. Students' learning abilities are really good enough to read or listen something higher than their present learning materials. What moved me more was the word caterpillar which has 4 syllables, but my students just started learning English for not more than 2 months. Also, students themselves got excited because they could get the correct answers about what I asked them. Most of students got involved in my class and in my picture book. Of course, when they got the right answer, they would get a star for their team. The funniest thing was that when I asked to guess what color was the last picture, they gave me different colors but I said they were all right and they were very confused and wondered why. Before I showed them the last picture, I asked to think it over and tell me why. One of them raised her hand and said" the caterpillar became a butterfly now." It really impressed me. 
Reflection III

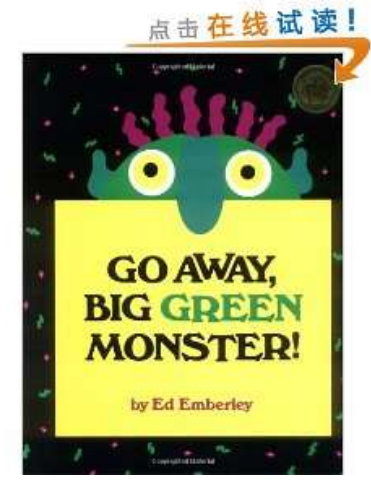

When I showed the book "Go away, big green monster!" , all my students were letting out a cry. They were all attracted by the cover because its there was a monster on the cover. I asked them colors and body parts then moved to describe the color of the body parts and they all did very well because they learned the colors in unit 2 of their text books and body parts in Unit 3. When I stopped at the one sixth of the book, they all felt a little disappointed. They seemed interested in this book but I had to pause there because picture-books are only part of my lessons and I do not use pictures books to teach them but to improve their interests, listening, speaking and reading skills. And also this is a little trick for teachers to teach students. We don't finish good things at one time. We let students expect you to come to classroom with a good story book. When I finished five sixth of this book, I asked them to borrow this book from school library and read it to dad and mum. Luckily, after class, my students all rushed to library to borrow this book and this made me feel very successful and proud.

Reflection IV the foot book (Body part and numbers)

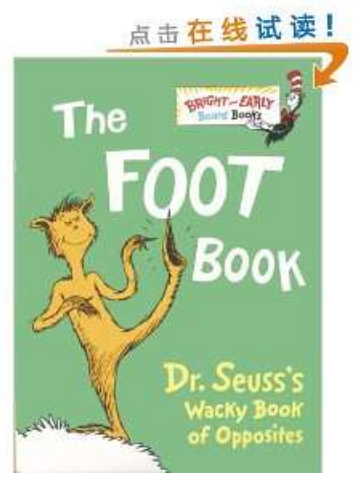

When I showed the book to the students, they were all attracted by the cover. They all thought it to be a monster book. The funniest thing was that when I asked "how many feet do I have?" all the students answered "two", but I said I had "'four", they were all surprised. They soon said "arms are not feet". When I said" I have 2 arms and 4 feet", they were completely 
lost. Then I asked:" Do you know why?" but they all shook their heads. I asked a boy stand behind me and hold me tight and said "I have 4 feet, see?". All the students laughed happily. When I said," I have 6 feet", another boy ran fast to me voluntarily and stood behind the boy who was behind me. Then the "snake" became longer and longer.

When I finished the whole book, I found there were too many adjectives for them to remember, but some of the students could the most of the adjectives. Of course, my object was that they could say left and right, foot and feet, how many feet and numbers 1-48. Their abilities to learn really impressed me a lot.

Reflection V No, David (Rules)

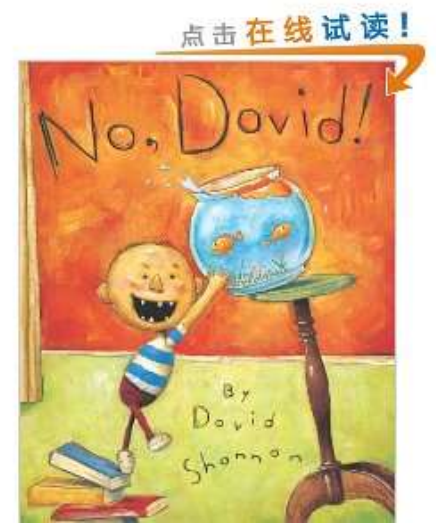

When I showed this book, all the students laughed. When I asked them why they were laughing, they said this boy was funny and this boy was ugly. When I asked them what the boy was doing, one of them said he was to eat the fish and another one said he was to catch the fish.

Every time I explained a picture and my students could understand and then they would say," No, David." They are quick learners and they can do say something above their English level.

Since then, my students can say" no ...", while I am pointing to someone who is not listening to my class. It impresses me a lot. Students learning abilities are really impressive and more than you can think of. While I finished this five books, I thought I should read more English picture books to them and they should read more at home and at library.

\section{Appendix IV pre-test}

I. Listen and circle the words you hear
1. A. pen
B. pencil
2. A. ruler
B. Crayon
3. A. eraser
B. Pencil box
4. A. pencil
B. Ruler
5. A. book
B. Bag
6. A. hello
B. $\mathrm{Hi}$
7. A. welcome B. OK
8. goodbye B. Bye 
II.Llisten and number
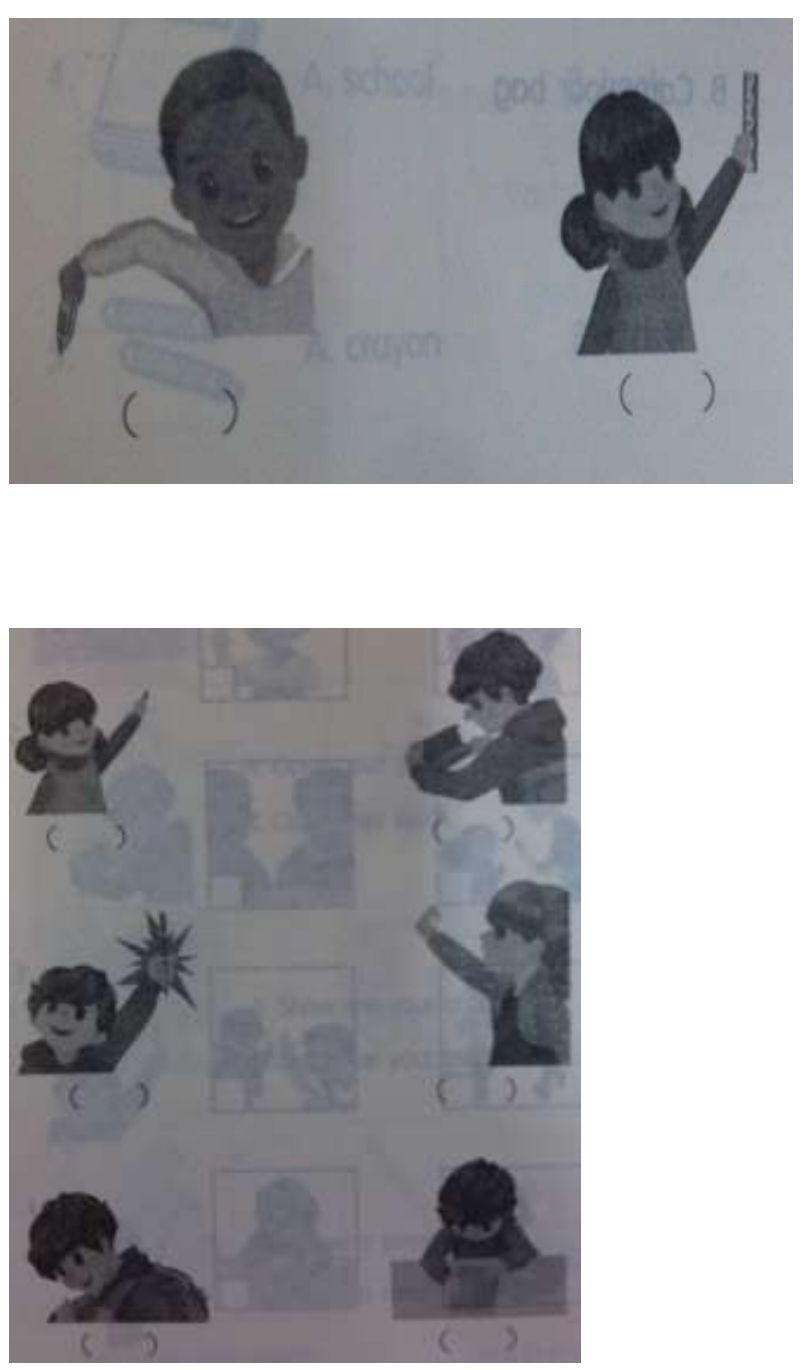
III. Listen and" ل/".

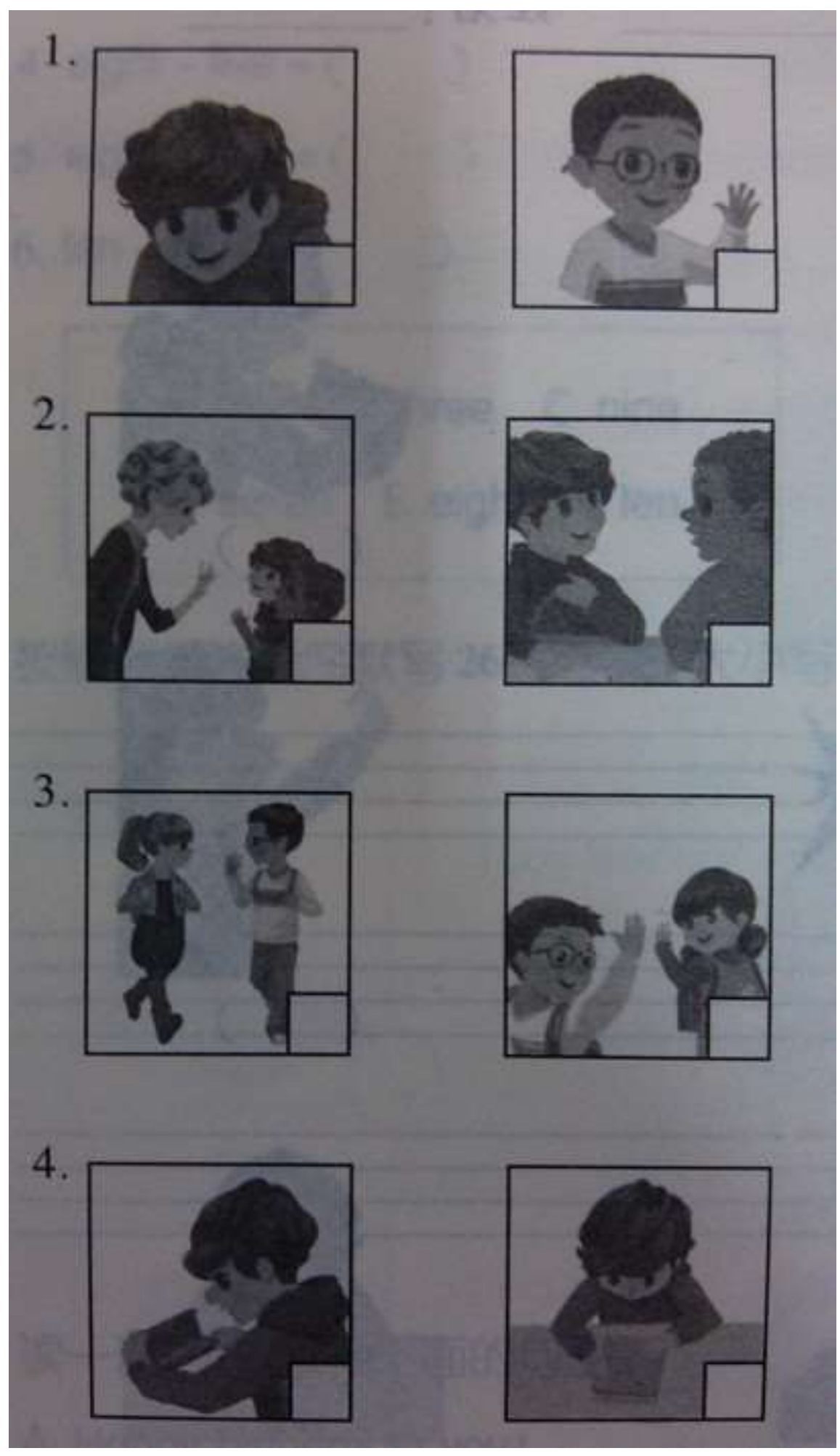


IV. listen and choose what you hear

1. A. Hello! I'm Wu Yifan. B. Hi! I'm Sarah.

2. A. Show me your eraser. B. Show me your crayon.

3. A. Open your pencil box. B. Close your pencil box.

4. A. I have a book. B. I have a ruler.

5. A. Close your book. B. Carry your bag.

\section{Read and circle}

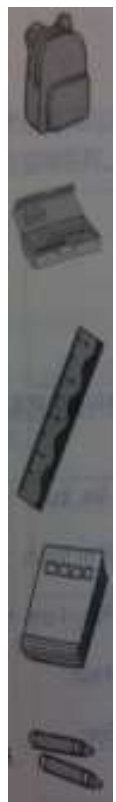

$\begin{array}{lll}\text { 1. A. bag } & \text { B. book }\end{array}$

$\begin{array}{lll}\text { 2. A. pencil } & \text { B. pencil box }\end{array}$

$\begin{array}{lll}\text { 3. } & \text { A. pen } & \text { B. ruler }\end{array}$

$\begin{array}{lll}\text { 4. A. school } & \text { B. book }\end{array}$

5. A. crayon B. eraser

\section{VI. look and choose}

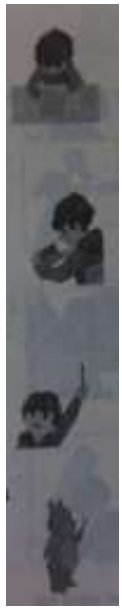

1. A. Show me your eraser.

B. Close your book.

2. A. Open your pencil box.

B. Close your book.

3. A. Show me your crayon.

$B$. how me your pen.

4. A. I have a pencil.

$B$. I have a ruler. 
VII. read and put "V" or " $x$ " in the circles

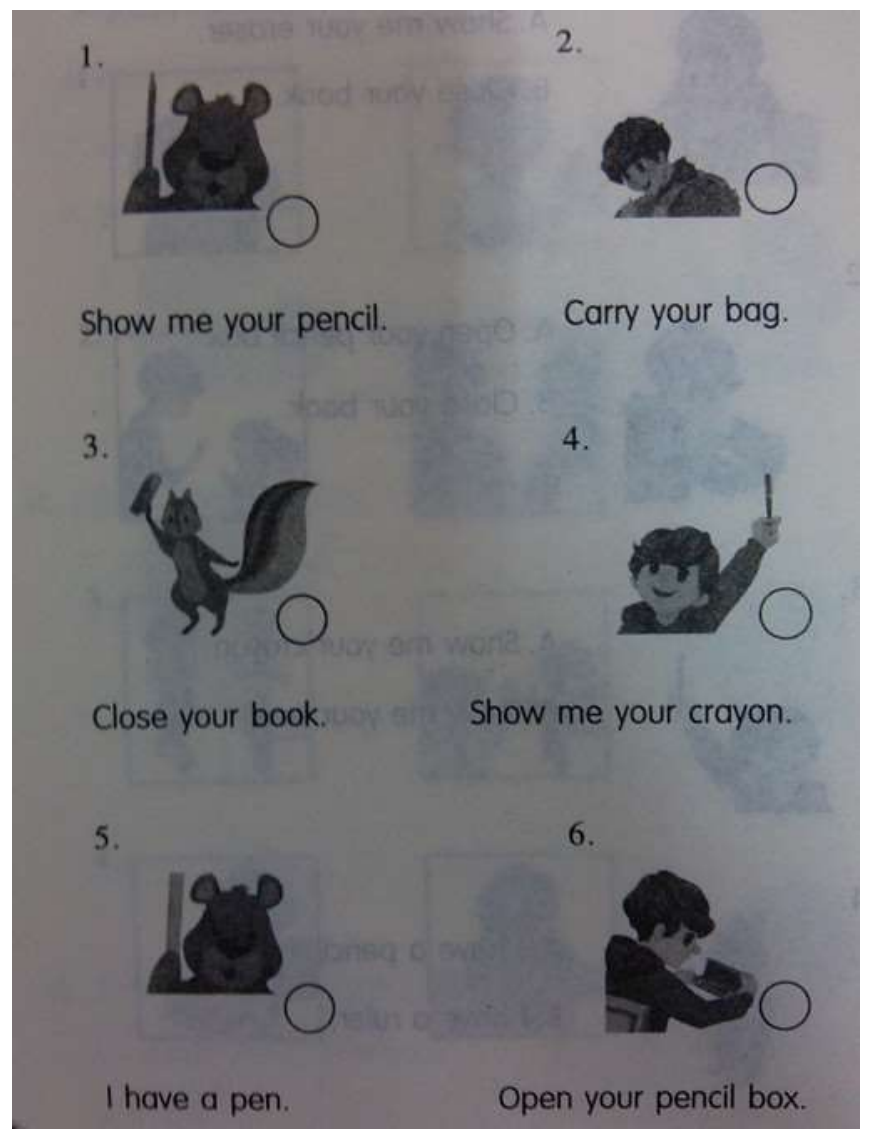

VIII. match
A.
q
D.
$\mathrm{n}$
E.
d
$\mathrm{N}$.
a
Q.
e
F.
f 
IX. match
( ) 1. Hi!
A. Me, too.
( ) 2. Goodbye!
B. I'm Sarah
( ) 3. What's your name?
C. Yes, i am.
( ) 4. Are you John?
D. Hello!
( ) 5. I have a bag.
E. Bye!

\section{Appendix V Post-test}

I. listen, draw and color

\begin{tabular}{|l|l|}
1. & \multicolumn{2}{l|}{2.} \\
\hline & \\
& \\
\hline 3. & \\
\hline & \\
& \\
& \\
\hline 5. & \\
\hline & \\
\hline & \\
\hline
\end{tabular}




\section{Listen and " $\sqrt{ }$ "}

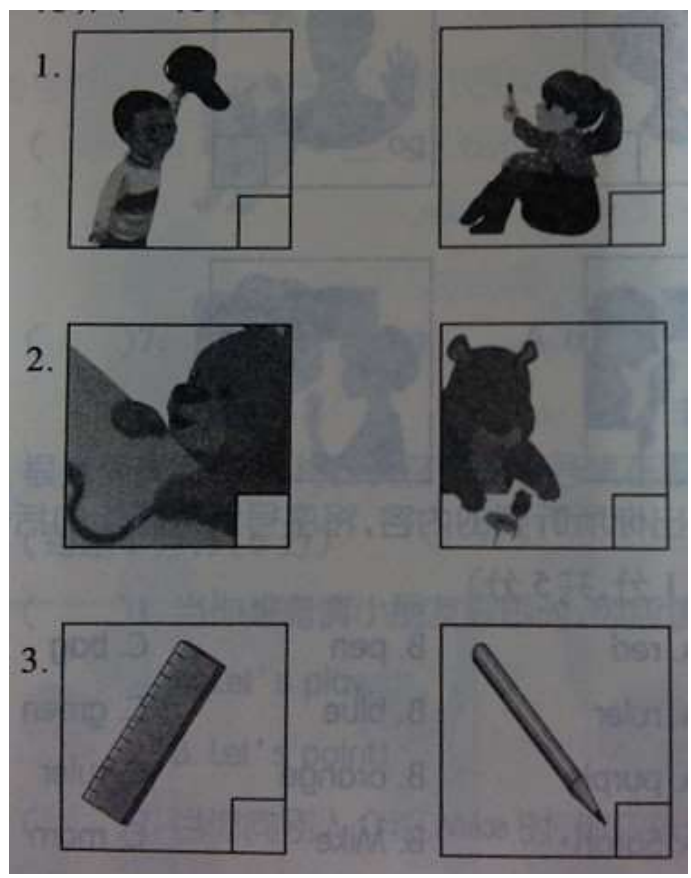

III. Listen and choose what you hear
( ) 1. A. red
B. pen
C. bag
( ) 2. A. ruler
B. blue
C. green
( ) 3. A. purple
B. orange
C. Ruler
( ) 4. A. Sarah
B.Mike
C. Mom
( ) 5. A. white
B. Miss White
C. Mr White

IV. listen and choose the response sentence
( ). 1. A. good morning!
B. Good afternoon!
( ) 2. A. OK!
B. Bye!
( ) 3. A. Oh, no!
B. Nice to meet you, too!
( ) 4. A. Goodbye!
B. Fine, thank you.
( ) 5. A. Bye!
B. Ok! 
V. listen and choose the correct sentence on the blanks

A: Mike.

B: Good morning, Sarah.

A: ?

B: I'm fine, thanks.

A: This is my friend, John.

B:

C: Nice to meet you, too.

A: !

B,C: Great!

Nice to meet you

B. Good morning.

C. Let's paint

D. How are you

VI. Read and put the words below in category

Red pencil book white blue ruler

Crayon orange brown pencil-box

Colors:

Stationary:

VII. Read and fill the letters

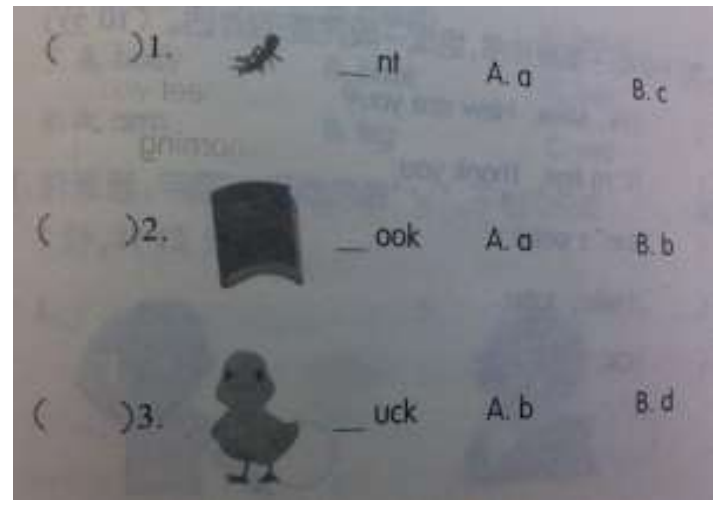




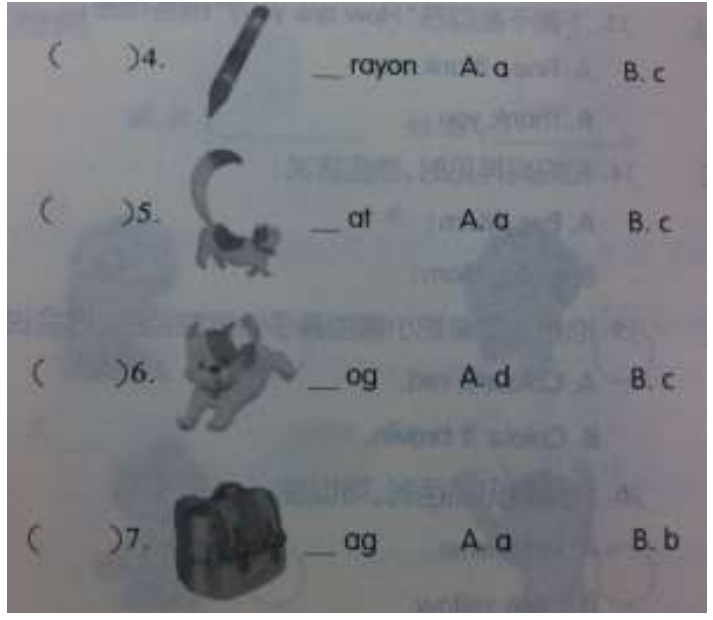

VIII. Read and choose

( ) 1. You want to invite friends to paint, you say?

A. Let's play.

B. Let's paint!

( ) 2. You introduce mike to others, you say?

A. I'm Mike.

B. This is Mike.

( ) 3. Which one can't answer how are you?

A. Fine, thank you.

B. Thank you.

( ) 4. How do you say goodbye to mum?

A. Bye, mom!

B. Hello, mom!

( ) 5. You want your desk mate to color the bear nose brown you say?

A. Color it red.

B. Color it brown.

( ) 6 . When you see blue, you say?

A. I see blue.

B. I see yellow.

IX. Read and match。 

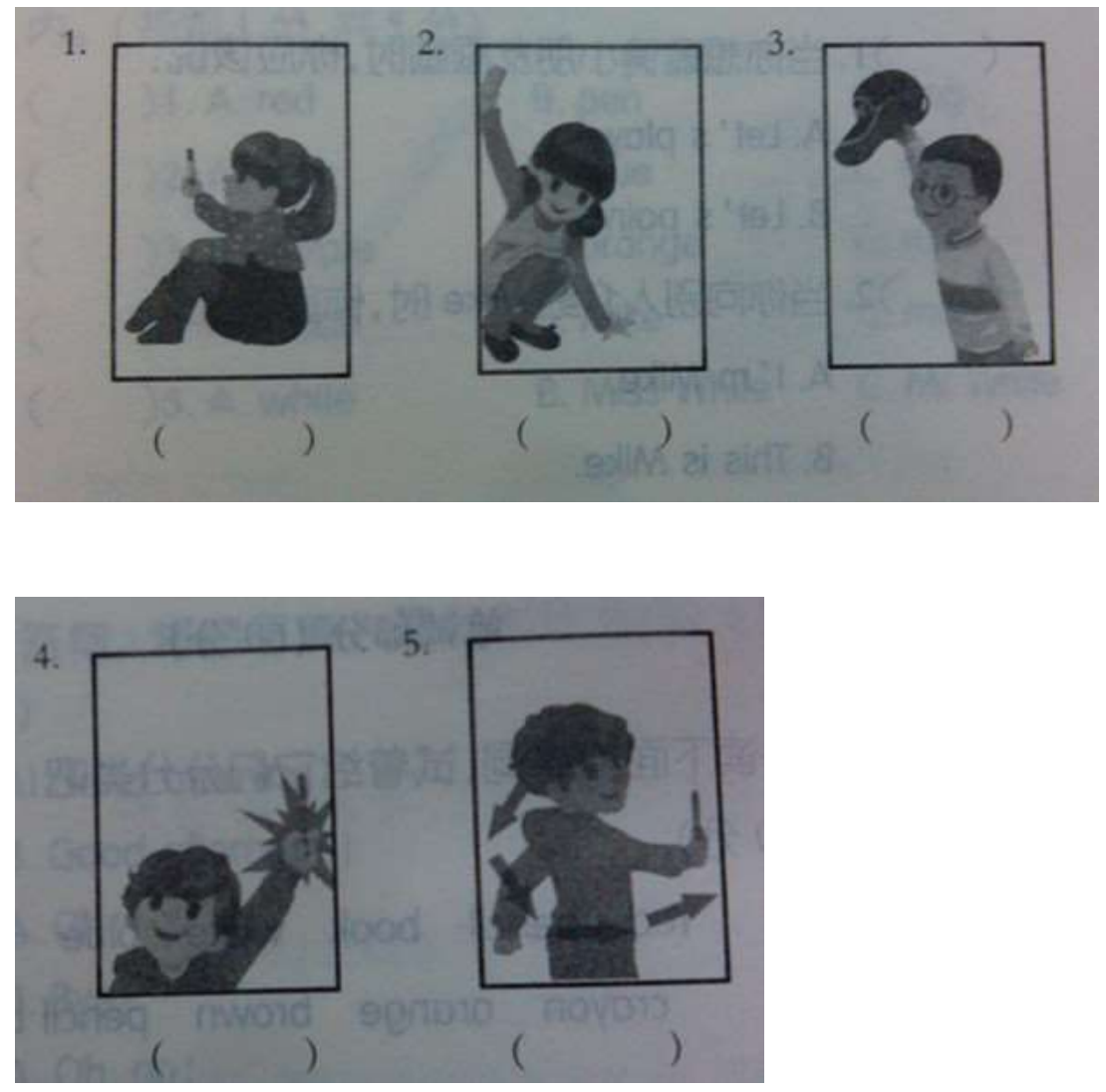
A. Show me your pen.
B. Sit down.
C. Stand up.
D. Turn around.
E. Touch the ground.

$X$. rearrange the sentences in correct order
( ) Hi, Mike. How are you?
( ) I'm fine. Thank you.
( ) Let's paint.
( ) Hello, John.
( ) Ok.

\section{Appendix VI. Questionnaire}

(Picture books teaching questionnaire)

age: gender: 
Dear students,

We hope that we can get some ideas about picture books teaching through this questionnaire. There is no right or wrong about your answer and your answer will not affect your test scores. Just tell us what you think. Thank

Choose what you think and tick (just one answer).

1. Which one do you prefer, the original class or picture books?

a. The original class

b. Picture books

2. Has your interest been improved in English listening, speaking and reading?
a. nothing improved
b. Improved a little
c. Improved a lot

3. How much do you understand of the picture book teacher told?
a. Nothing
b. A little
c. Most of them
d. All of them

4. Do you predict what will happen in the story?
a. Never
b. Sometimes
c. Usually

5. Do you think you English I istening, speaking and reading has been improved during the past 2 and a half months?
a. Nothing improved
b. Improved a little
c. Improved a lot

\section{Appendix VII. Students Interview Notes}

Number of students: 48 , here appeared 5.

1. do you like listening to and reading picture books?

Jasmine: yes.

Daphne : Yes

Lily : Yes

Felix : Yes

Qin : Yes

2. what progress have you made through listening to and reading picture books?

Jasmine: English reading and listening.

Daphne: I can read picture books myself.

Lily : My English score is higher.

Felix : My vocabulary is bigger. 
Qin : English speaking is improved.

3. what you think of picture books?

Jasmine: I enjoyed Mr. EZ telling stories.(the teacher's name is EZ)

Daphne : I found picture books interesting.

Lily : I feel that school should buy more picture books.

Felix : I enjoyed Mr. EZ reading picture books and I enjoyed reading them too.

Qin : I enjoyed Mr. EZ reading picture books.

4. can you give any suggestions about picture books reading class?

Jasmine: I hope Mr. EZ can read a book every class.

Daphne : I hope Mr. EZ can read an interesting book every class.

Lily : I hope my teacher can tell us a story each class.

Felix : I hope my teacher can read us a story book every day.

Qin: I hope my teacher can read more books to us. 
Appendix VII

The project flow chart
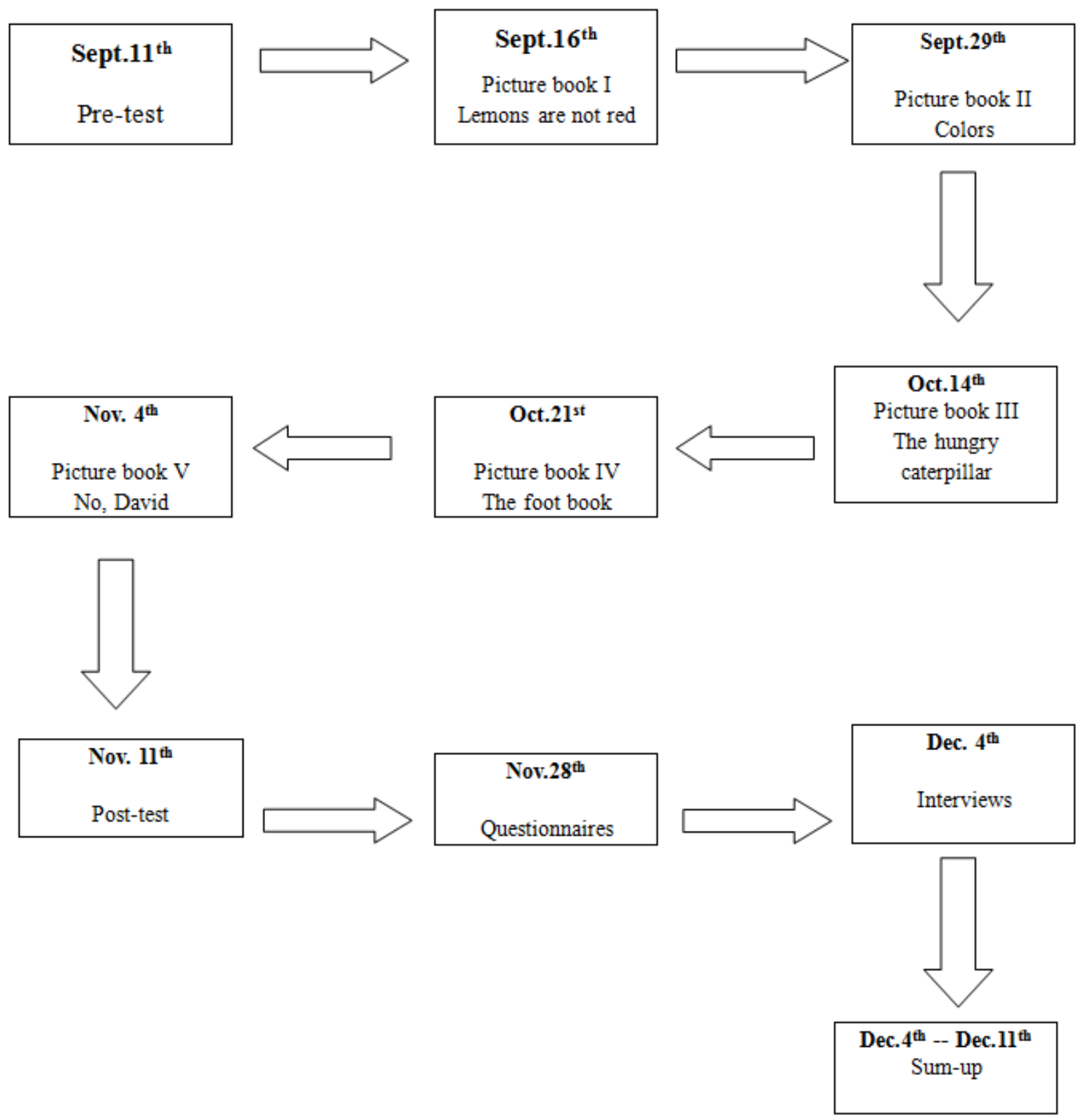